Pirineos, 139: 27 a 46, JACA; 1992

\title{
ANALYSIS OF THE ROLE OF AGRICULTURAL ABANDONED TERRACES ON THE HYDROLOGY AND SEDIMENT DYNAMICS IN A SMALL MOUNTAINOUS BASIN. (HIGH LLOBREGAT, EASTERN PYRENEES) ${ }^{1}$
}

\author{
Llorens, P.*; LATRon, J. ${ }^{\star \star} \&$ Gallapt, F. ${ }^{\star}$
}

\begin{abstract}
In the Cal Parisa basin (36 Ha) a sub-basin of 17 Ha was instrumented in 1989 in order to study the hydrological response and the sediment dynamics of mountainous areas highly modified by traditional agriculture and now abandoned. The results show the preservative role of the agricultural terraces, characterized by a high water retention capacity and a very low sediment yield, in spite of significant amounts of sediment which are transferred within the basin but do not reach the outlet. During rainy periods the partial saturation of terraces produces important runoff volumes quickly drained by the man made network of ditches, generating sharp runoff peaks. These ditches are shown therefore to be the elements of major hydrological and linear erosion risks. Nowadays the lack of drainage networkmaintenance, as a result of land abandonment, has caused disorganization which may have some important hydro-geomorphological and land conservation consequences.
\end{abstract}

RESUMEN.-Análisis del papel de las terrazas de cultivo abandonadas en la hidrologia y dinámica de sedimentos en una pequeña cuenca de montaña. Dentro de la cuenca de Cal Parisa (36 Ha) una subcuenca de $17 \mathrm{Ha} \mathrm{de}$ superficie fue instrumentada en 1989 para el estudio de la respuesta hidrológica y la dinámica de sedimentos de áreas montañosas altamente modificadas por la agricultura tradicionaly actualmente en estado de abandono. Los resultados obtenidos muestran el papel conservador del sistema de terrazas o bancales de cultivo que se manifiesta en una alta capacidad de retención hídrica y una muy baja producción de sedimentos, a pesar de que dentro de la cuenca se

1 Received, March 1992

* Institut de Ciències de la Terra Jaume Almera Ap. 30102, 08080 Barcelona

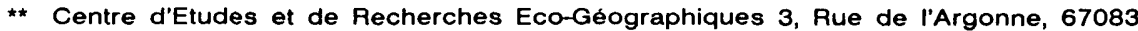
Strasbourg Cedex, France. 
movilizan cantidades significativas de sedimentos que no alcanzanel exutorio. En periodos lluviosos la saturación parcial de las terrazas de cultivo produce importantes volúmenes de escorrentía que al ser canalizados rápidamente por el sistema de drenajes artificiales provocan marcados picos de crecida, presentándose en consecuencia estos canales como los elementos de mayor riesgo hidrológico y de erosión lineal. Actualmente el cese en el mantenimiento del sistema de drenajes, como resultado del abandono de las labores agricolas, provoca su desorganización, lo que puede acarrear importantes consecuencias hidrogeomofológicas como erosión en cárcavas y deslizamientos.

RESUMÉ- Analyse du rôle des terrasses agricoles abandonnées sur I'hydrologie et la dynamique des sediments dans un petit bassin versant de montagne. Au sein du bassin versant de Cal Parisa (36 Ha) un sous-bassin de 17 Ha fut instrumenté en 1989 dans le but d'étudier la réponse hydrologique et ladynamique des sédiments en régions montagneuses fortement marquées par l'agriculture traditionelle et actuellement abandonnées. Les résultats obtenus mettent en évidence le róle conservateur du système de terrasses qui se caractérise par une grande capacité de rétention hydrique ainsi qu'une très faible production de sédiments, malgré les volumes de sediments mobilisés dans le bassin mais qui n'atteignent pas l'éxutoire. Lors de périodes pluvieuses, la saturation partielle des terrasses de culture produit d'importants volumes d'écoulement, qui, rapidement canalisés par le système de drainage artificiel, provoquent des pics de crue marqués, faisant par conséquent de ces canaux de drainage des éléments majeurs de risque hydrologique et d'érosion linéaire. Aujourd'hui, l'absence d'entretien du réseau de drainage, résultant de l'abandon des pratiques agricoles, entraine sa désorganisation susceptible de présenter d'importantes conséquences hydro-géomorphologiques comme le creusement de ravins et les glissements de terrain.

\section{Introduction}

Mid-Pyrenean mountains have been affected by human activity to the point that, in some areas, not only vegetation cover but also microtopography and elementary drainage networks have been strongly modified.

The implications of these changes in the hydrological processes have been poorly described, and the available distributed or semi-distributed hydrological models are inadequate in taking them into account as well. Furthermore, these geoecological systems have been organized with a great deal of manpower, which is also necessary to maintain its existence (see LASANTA et RUIZ, 1990). Further evolution after land abandonment is of high environmental relevance, especially concerning water resources.

This paper aims to describe, the hydrological and sediment dynamics behaviour of a small area selected as a representative of recently abandoned mountain agricultural zones (LLORENS, 1991) prone to gully erosion and landsliding, to make some estimations on the hydromorphological changes introduced by terracing (LATRON, 1991), and to infer some of the medium and long-term consequences of abandonment. 


\section{The study area}

\subsection{Main characteristics:}

The Cal Parisa basin is located at the headwaters of the Llobregat river near Vallcebre (Eastern Spanish Pyrenees), a very active area, prone to gully erosion and landsliding (see CLOTET et al., 1988, BALASCH et al., 1992).

This small basin, which takes the form of a south-east facing hillslope, occupies an area of $36 \mathrm{Ha}$ ranging between 1400 and $1700 \mathrm{~m}$ a.s.l., with $70 \%$ of the total surface between 1420 and $1560 \mathrm{~m}$. This is a second order basin that is constituted by two elementary basins of 16.7 and $19.3 \mathrm{Ha}$, subsequently referred to as left and right sub-basins.

The hillslope gradients range from 5 to over $70 \%$, but almost $60 \%$ of the basin shows gentle gradients from 10 to $30 \%$.

The basin enjoys a submediterranean climate where the main perturbations are brought about by the N-NW dominant winds (MARTIN-VIDE et al., 1989). The mean annual precipitation measured between 1983 and 1990 at the "Instituto Meteorológico Nacional" station of Vallcebre-Rectoria (1119 $\mathrm{m}$ a.s.l.) is about $851 \mathrm{~mm}$ showing a great interannual variability (standard deviation of $206 \mathrm{~mm}$ ). The annual distribution of precipitations shows 3 rainfall peaks in autumn, spring and august, the last one due to convective rainstorms (fig. 1).

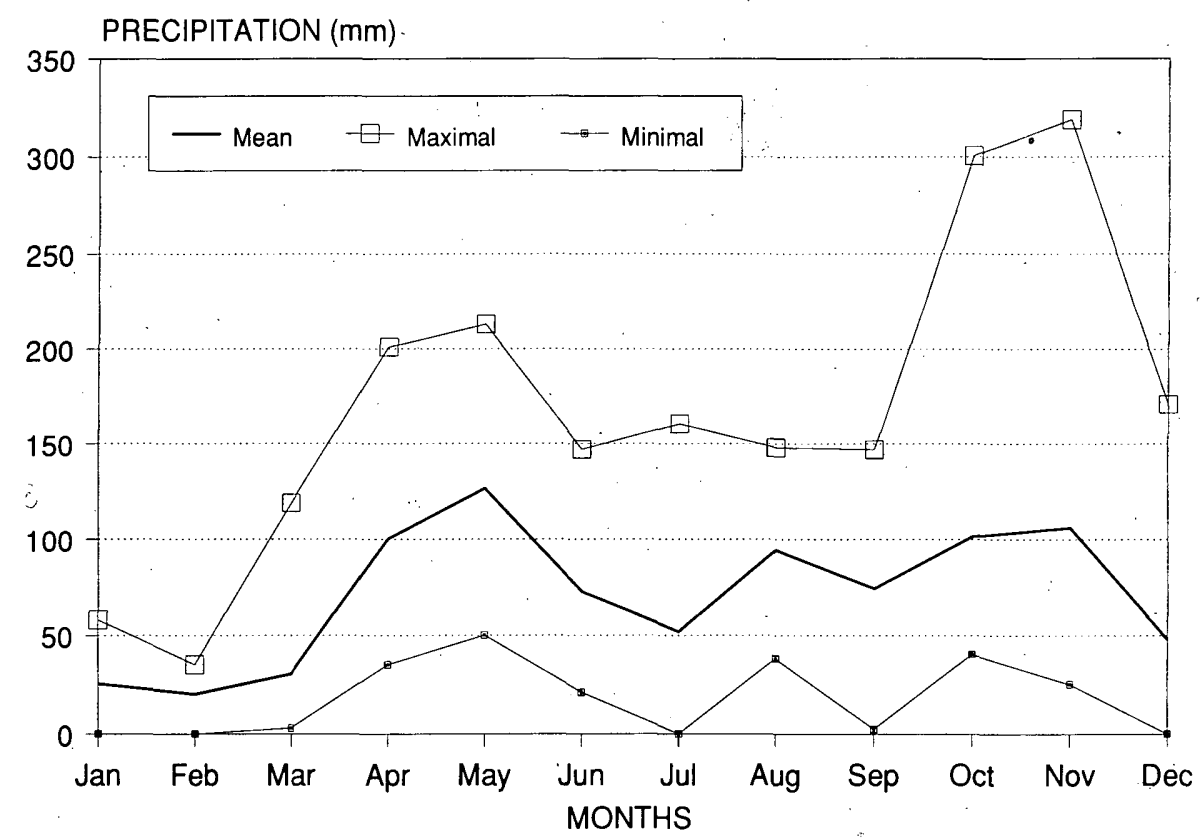

Figure 1: Mean, minimal and maximal monthly precipitations at Vallcebre station (1.119 m. a.s.l.) between 1983 and 1990. (Precipitaciones mensuales medias, minimas y máximas en li: estación de Vallcebre (1.119 m. de altitud) durante el periodo 1983-1990.) 
The mean annual temperature, registered at the Cal Parisa station ( 1480 ma.s.I.) between july 1989 and december 1990 , is $9.2^{\circ} \mathrm{C}$, with a great monthly and daily temperature range (fig. 2).

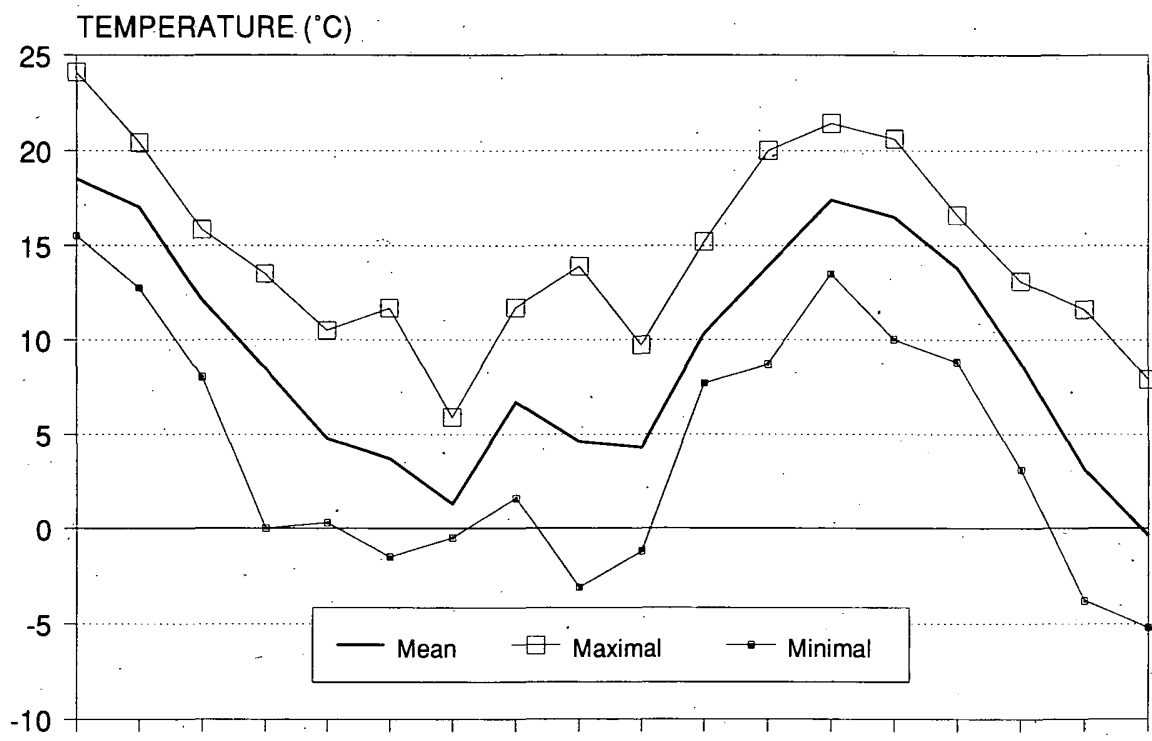

Jul Aug Sep Oct Nov Dec Jan Feb Mar Apr May Jun Jul Aug Sep Oct Nov Dec MONTHS

Figure 2: Mean, minimal and maximal monthly values of mean daily temperatures at Cal Parisa station (1.480 m. a.s.I.) for the study period (July 1989 - December 1990.) (Valores mensuales medios, minimos y máximos de las temperaturas medias diarias en la estación de Cal Parisa (1.480 m. de altitud) durante el periodo de estudio (julio 1989 -diciembre 1990.)

The main part of the basin lies on a smectite rich mudstone of the upper Cretaceous (Garumnian facies). In the upper part of the basin there is a massif lacustrine limestone bed folded into a nearly vertical plane.

The clayey bedrock has a silty texture due to its high calcite content, and shows a slaking behaviour which strongly contrasts with the high stability of the soils they develop (SOLE et al., 1992).

\subsection{Geoecological impact of landuse:}

The human modifications made for the agricultural use of the basin induced important changes in vegetation cover, topography and water circulation.

The original forest cover (Quercus pubescens) was removed to permit the development of traditional agricultural practices, which reached their 
maximal expansion during the middle XIX century and lasted until the sixties when farming was substituted by extensive cattle stockbreeding. Nowadays half of the basin, roughly corresponding to the left sub-basin, is covered by mesophile and xerophile grasslands, typical of recently abandoned fields, with some small patches of hydrophile species. The remainder are marginal areas, earlier abandoned, overgrown with a Pinus sylvestris stand that tends to invade the neighbouring areas.

These agricultural practices also caused wide variations in the basin topography because of the construction of terraces, which made the work on this steep hillslope easier. Terraces show typically 3 to $6 \mathrm{~m}$ wide flat or gently dipping areas and steep banks sheltered by man-made stone walls. The total terraced surface represents about $40 \%$ of the total area and forms the main geoecological unit of the basin (fig. 3 ).

Terraced topography promote the outcrop of phreatic waters in the inner parts of terraces, where there is no or very little soil, causing the development of areas almost always saturated. In order to drain such areas and to prevent wild runoff across the terrace system, a network of shallow man-made ditches was constructed increasing more than $50 \%$ the total length of the drainage net.

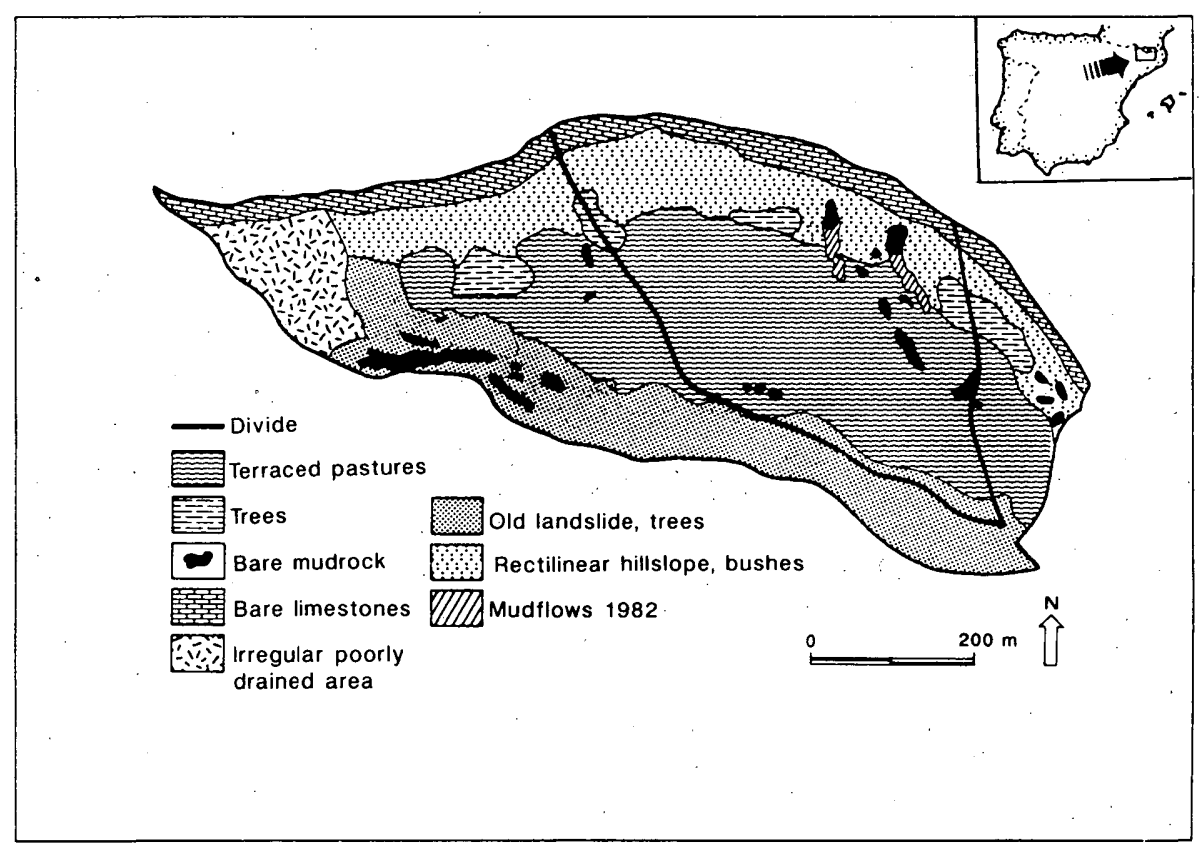

Figure 3: Main geoecological units map of the Cal Parisa basin. (Mapa de las principales unidades geoecologicas de la Cuenca de Cal Parisa.) 
PIRINEOS 139

\section{Methods}

\subsection{Meteorological, hydrologicaland sediment transportmonitoring design:}

The Cal Parisa basin has been studied since 1988, but the instrumentation of the more man modified sub-basin (left one), in July 1989, has given a general pattern of the hydrological and sediment transport response (LLORENS, 1991).

The instrumental design consists of (LLORENS \& GALLART, 1992):

-One meteorological station with global radiation, precipitation, air temperature and humidity, wind velocity and direction measurements.

-Three scattered rain-recorders.

-One hydrometrical station based on aH flume with continuous recording of water discharge, temperature and conductivity.

-A sampling station with both a time-depending automatic sampler and a stage sampler.

All these instruments are connected to several data loggers that record the variables every five minutes.

\subsection{Cartographical study of hydrological features:}

Together with the instrumentation of the more man modified sub-basin, several cartographic works were made in order to describe some specific features of the whole basin.

Two main maps were drawn up, a saturated areas and drainage network map and a bare areas map.

a) The saturated areas and drainage network map:

This map is based on the observation of the hydrophile (Molinia coerulea) vegetation that grows on the frequently saturated areas, its typical yellowish colour in early autumn allows quite an accurate mapping of these areas. On this map (fig. 4) we can observe that about $7 \%$ of the total basin is often saturated. The origin of such saturated areas is the outcrop of phreatic waters induced in many cases by the crossing of the phreatic level by the terraced topography. In fact, it is possible to distinguish two types of saturated areas on the basin:

On the one hand, often bordering natural drainage axes, the natural saturated areas, whose presence is linked to natural characteristics of the basin as the gentle gradient or the hillslope bottom position.

On the other hand, the anthropic saturated areas, whose location and distribution is clearly related to the construction of terraces, in some contradiction with the original topography of the basin. In order to drain these anthropic areas, a network of man made ditches was constructed increasing about $50 \%$ the total network length as it appears on the map that differentiates the types of drainage pathways found in the basin.

b) The bare areas map: 


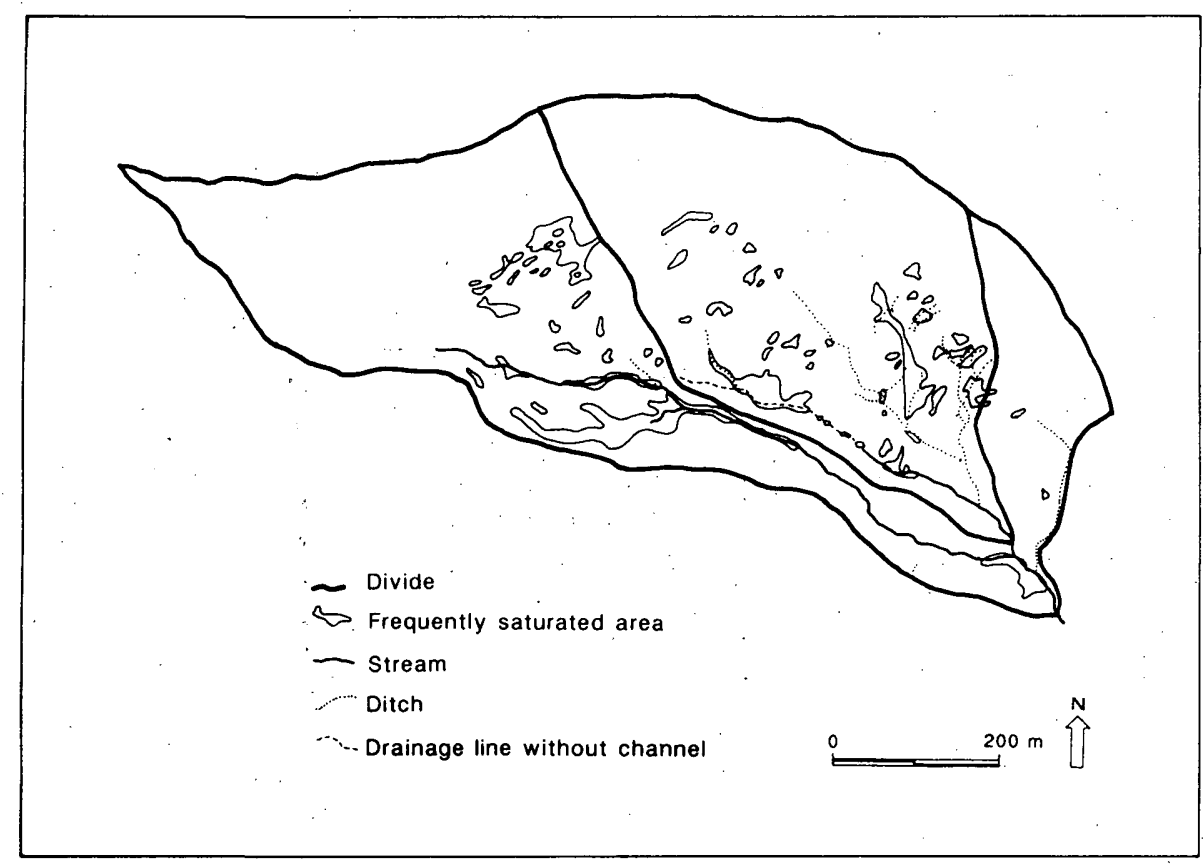

Figure 4: Drainage network and saturated areas map of the Cal Parisa basin. (Mapa de la red de drenaje y las areas saturadas de la Cuenca de Cal Parisa.)

Obtained by photo-interpretation, guided by field observation, the bare areas map shows the spatial distribution of the areas where the clayey bedrock outcrops, promoting the occurrence of intense erosion processes that lead to a microtopography of rills and small gullies. These areas, which constitute the main source of sediments in the basin, can be divided in two classes:

The two shallow landslides (mudflows) scars triggered by the extreme event of November 1982 (GALLART \& CLOTET, 1988), these occurred at the foot of the limestone cliff, on the very steep rectilinear hillslope. These two scars, that have an area of respectively 0.06 and $0.05 \mathrm{Ha}$, have shown a tendency towards linear erosion rather than rim retreat.

The other bare areas are much smaller and characterized by a very scattered vegetation cover growing on a silty bedrock where stonepavements are abundant.

Both georeferenced maps were digitized and entered in a Geographical Information System (ERDAS) in order to allow their confrontation with other kinds of information like the one delivered by D.T.M. also available on ERDAS.

This D.T.M. of the basin was obtained at the Institut Cartogràfic de Catalunya, by photogrammetry (using the automatic correlation system 
GESTALT GPM IV) on aerial photographs at scale $1 / 22000$. The resulting georeferenced D.T.M. shows a horizontal resolution of $15 \mathrm{~m}$ and its handling in the G.I.S. has given the maps of altitudes, gradients and orientations.

The D.T.M. data were then transferred from the G.I.S. to calculate the TOPMODEL TOpographical Index of each pixel using a recently developed algorithm (QUINN ET AL. 1990). The results of this calculation were then transferred again to the G.I.S. to produce the map of the Topographical Index of the basin (fig. 5).

The transformation of the LAND files (GIS) in ASCll files and vice versa were carried out using the programmes ERDASCl and ASCERDAS (DEL BARRIO et al., 1990).

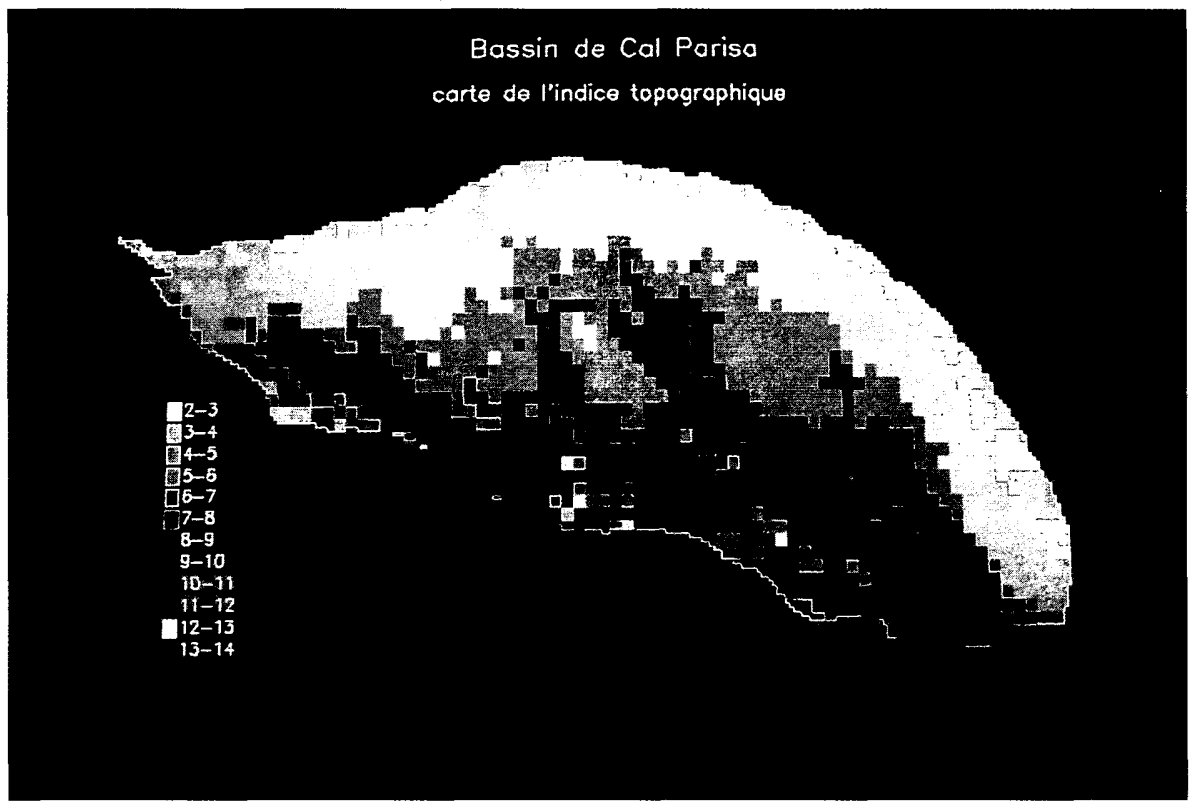

Figure 5: Topographical Index map of the Cal Parisa basin. (Mapa del Indice Topográfico de la Cuenca de Cal Parisa.)

\section{Results}

\subsection{Hydrological response:}

The monthly amounts of precipitation, during the studied period (July 1989 - December 1990), ranged from $1 \mathrm{~mm}$ to more than $150 \mathrm{~mm}$. Half the total precipitation of this period was collected during 5 months only (fig. 6). 


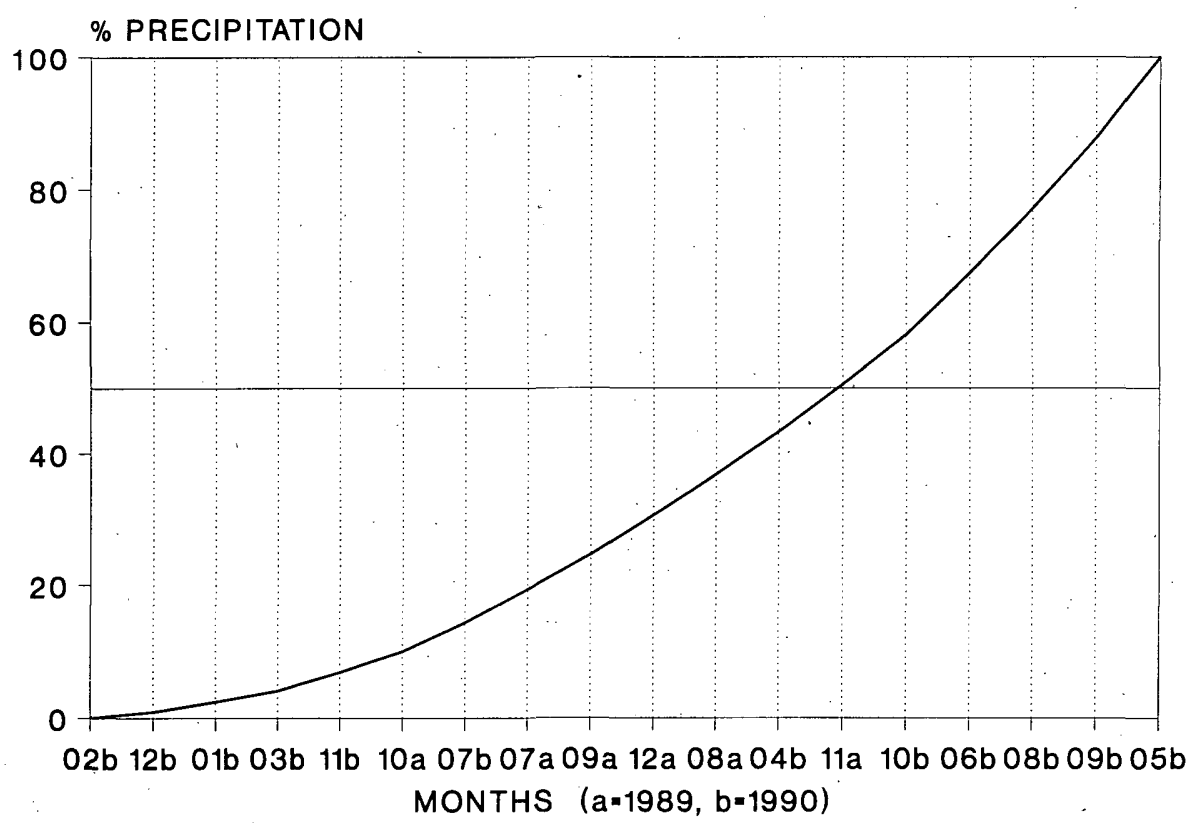

Figure 6: Cumulative ordered contribution of monthly precipitation to the total collected during the 18 studied months. (Contribución acumulada y ordenada de la precipitación mensual sobre el total colectado durante los 18 meses de estudio.)

For the left sub-basin nearly $90 \%$ of the total runoff was produced in 6 months only, with a mean runoff coefficient as low as about $14 \%$ for these months (fig. 7). This high variability is even more clear if we consider that during these 6 months, all the runoff (92\%) is produced by only one monthly event.

Rainfall distribution is one of the main factors which induce the higher variability of the hydrological response of the monitored sub-basin. The need for other factors to explain the runoff variability is demonstrated by the differences between the range of monthly contributions to rainfall and runoff (compare figs. 6 and 7).

On a monthly scaie, if the role of precipitation in runoff generation is analyzed, we observe that runoff is only produced during months with more than 12 days of rainfall and with a monthly rainfall volume per rainy day greater than $5 \mathrm{~mm}^{\text {day }}{ }^{-1}$.

But there are also few months above this threshold that do not produce runoff, showing again that the hydrological response of the sub-basin can not be explained only in terms of a rainfall-runoff relationship (fig. 8).

On an event scale, three simple rainfall-runoff models have been tested on the left sub-basin: the constant runoff coefficient, the Phi-index (see SINGH, 1988), and the constant loss (STEPHENSON \& MEADOWS, 1986). 


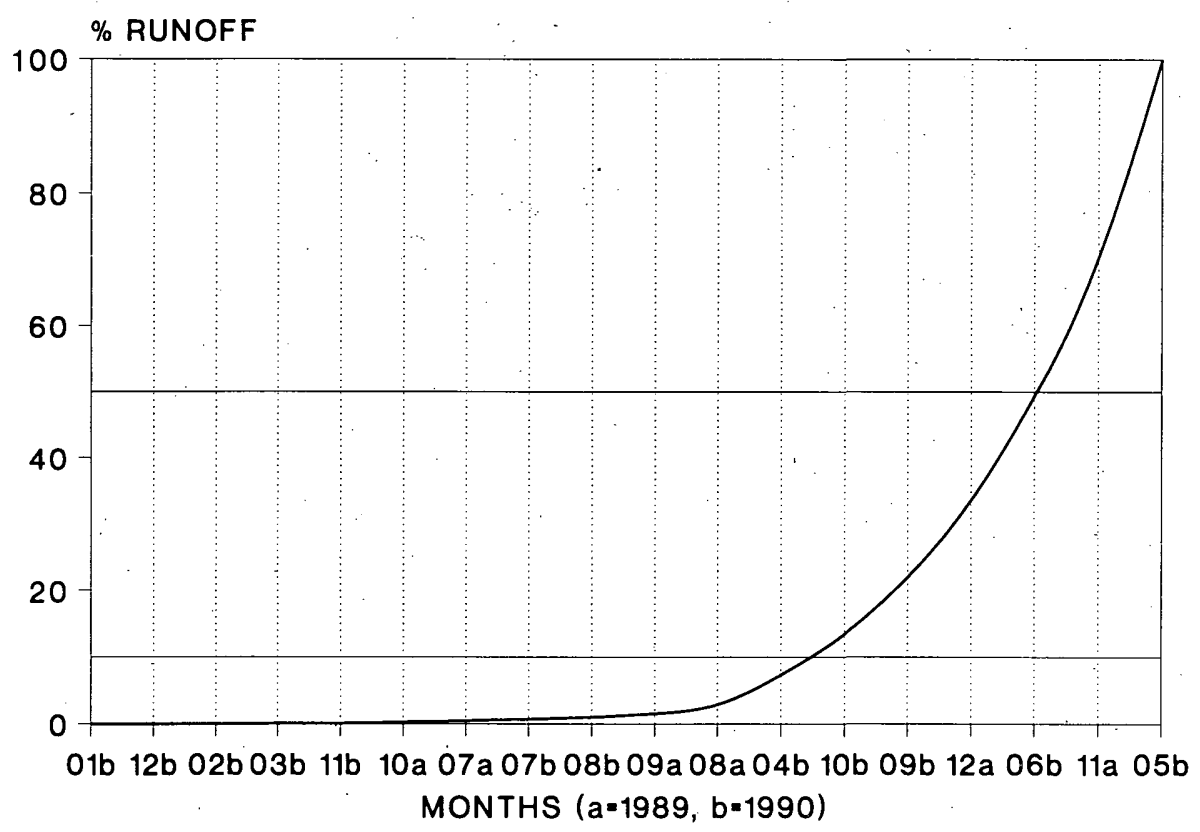

Figure 7: Cumulative ordered contribution of monthly runoff to the total measured during the 18 studied months (left sub-basin). (Contribución acumulada y ordenada de la escorrentia mensual sobre el total registrado durante los 18 meses de estudio (subcuenca izquierda.)

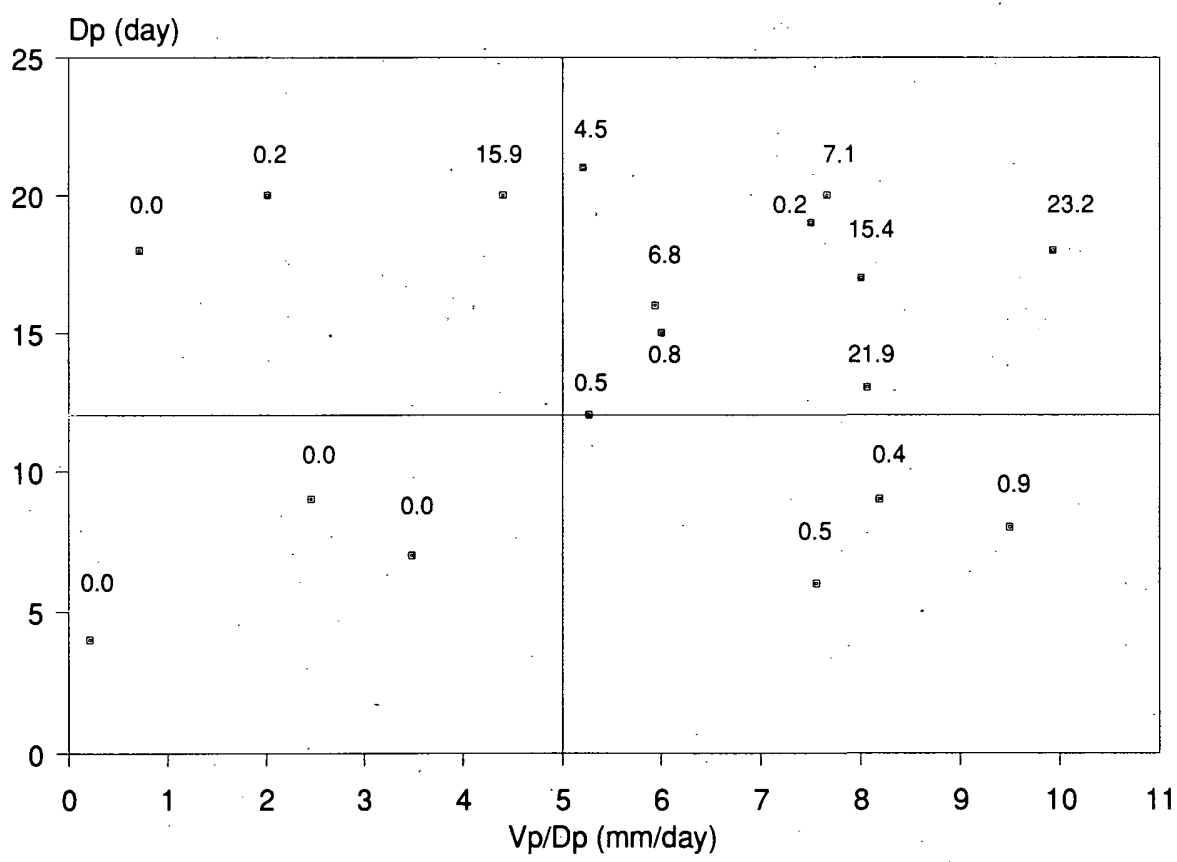

Figure 8: Relationship between monthly number of rainfall days and total volume per rainy day for the 18 studied months (left sub-basin). (Relación entre dias de lluvia por mes y volumen de precipitación por dia de lluvia para los 18 meses de estudio (subcuenca izquierda.) 
Although the best results are provided by the constant runoff coefficient model ( $w$ ith a mean runoff coefficient of $24.8 \%$ calculated from the 6 events that produced $92 \%$ of the total runoff recorded during the study period), it does not give adequate results for the prediction of runoff during summer events, when the measured runoff coefficient is much lower than the fixed one (fig. 9). Summer rainstorms up to $60 \mathrm{~mm}(58 \mathrm{~mm}$ in 26 hours, corresponding to two showers of 31 and $27 \mathrm{~mm}$ lasting 1 and 2 hours respectively, at 2 PM in two successive days) did not produce any runoff at the outlet, suggesting a clear influence of the previous moisture conditions of the sub-basin.

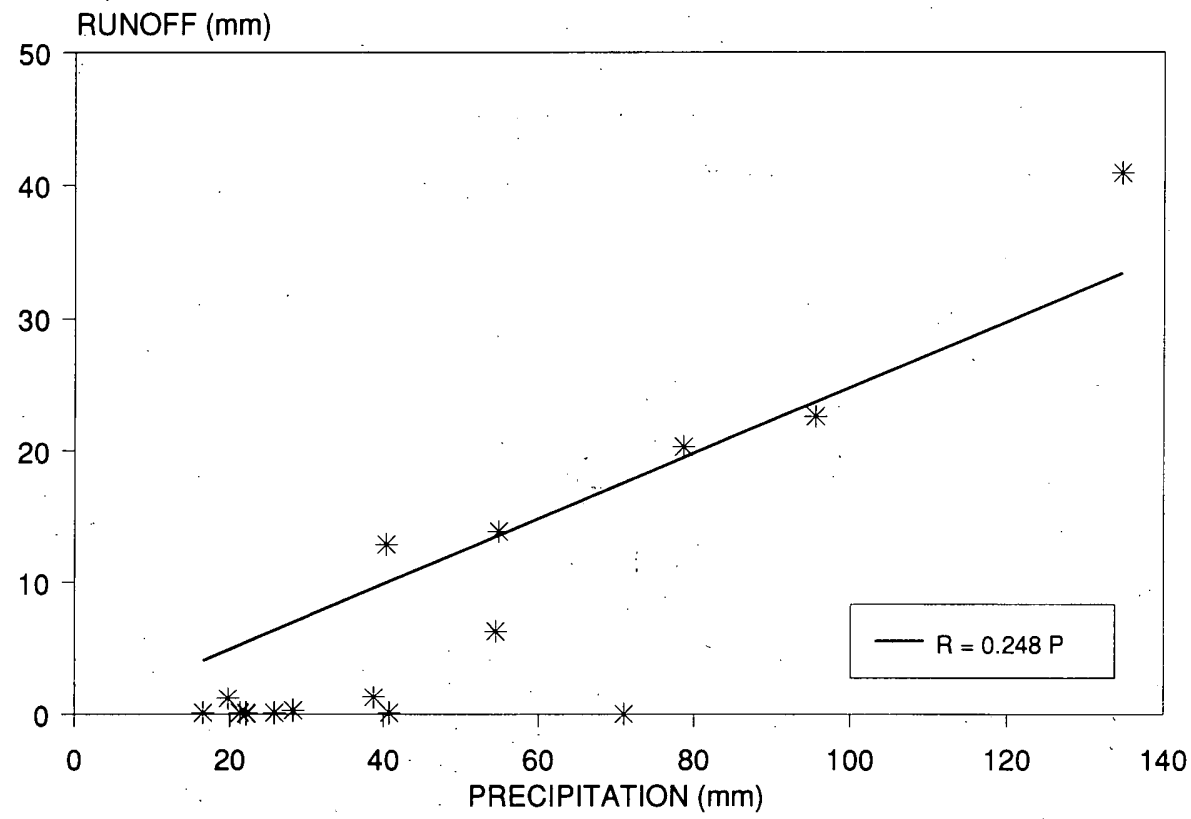

Figure 9: Measured rainfall-runoff relationship and comparison with a modelled one, using the Constant runoff coefficient model (left sub-basin). (Relación precipitación-escorrentia medida y comparación con el modelo de Coeficiente de escorrentía constante (subcuenca izquierda.)

The differences in previous conditions induce a great variability in rainfall volume before runoff is generated (ranging from $2 \mathrm{~mm}$ to $40 \mathrm{~mm}$ ) and also of the response time of the sub-basin. However, as soon as runoff is produced, the sub-basin shows a fairly similar hydrological response for all the observed events, characterized by one or few sharp peaks, the main one (typically $\mathrm{Q}^{\max } \geq 120 \mathrm{Is}^{-1}$ ) flowing out about half of the total runoff (fig. 10).

This set of hydrological features would indicate that for this sub-basin runoff generation is linked to saturation processes instead to Hortonian ones. In spite of the clayey character of the soils, their good structure and 
thickness, together with the terraced topography, enable high infiltration rates and retention capacities. However, there is field evidence that Hortonian runoff occurs in small areas of the basin where the clayey bedrock outcrops, but the runoff produced in these areas is infiltrated when it reaches the terraced area if this is not saturated enough.

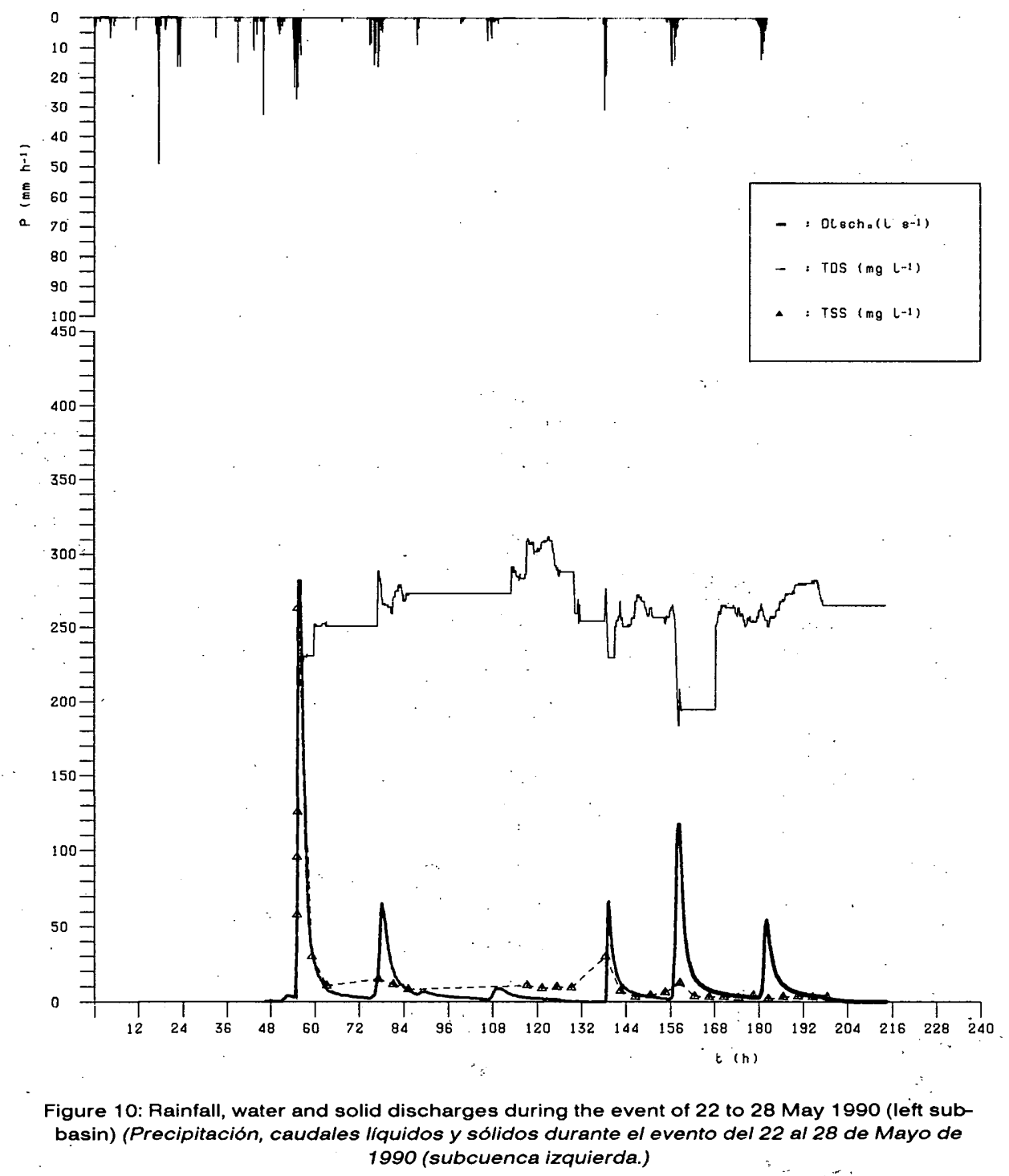




\subsection{Sediment dynamics:}

A preliminary Sediment Budget of the studied left sub-basin was carried out at four levels which are: first, a description of the sediment source and sink areas; second, evaluation of erosion rates in source areas; third, characterization of transport processes and sediments transfers; and last, assessment of sediment exportations.

As described before, sediment source areas represent, in terms of surface, only about $2 \%$ of the sub-basin. In spite of this, they play an important role in the short-term sediment budget and geomorphological evolution, mainly the landslide scars, due to the linear erosion processes that are developed causing an evolution towards gullied areas with relevant erosion rates. The remainder of the basin, mainly on vegetated terraces does not produce significant amounts of sediments.

The main sediment sink areas are located just at the foot of sediment source areas; this situation illustrates that, although erosion rates in landslide scars and small bare areas are significant, there is a high transfer discontinuity in the sub-basin. The sediments supplied by the source areas are therefore transported less than a hundred meters and deposited there. This interruption of sediment conveyance is due to marked discontinuities in topography and vegetation, the change in slope gradient and also the presence of grass vegetation, which occurs on the edge between a bare area and a terrace, blocks running waters and produces their infiltration and the deposition of the sediments they carry. Another factor, closely related to the previous one, which impedes sediments reaching the sub-basin outlet, is that most of the more productive source areas are disconnected from the drainage net. On the other hand, the drainage net itself shows longitudinal discontinuities of gradient and channel shape; well defined channels with active incisions alternate with wider and gentler vegetated poorly defined reaches where sediments are deposited.

The evaluation of erosion in landslide scars provide a mean erosion rate for the se areas of about $33 \mathrm{~mm}$ year ${ }^{-1}$ (LLORENS \& GALLART, 1991). On the other hand, erosion rates measured by CLOTET et al. (1988) in neighbouring badland areas contribute to the establishment of a medium-term erosion rate of the small bare areas of about $9 \mathrm{~mm}$ year ${ }^{1}$.

These erosion rates represent a sediment production of about 61 t year-1 for the sub-basin (19 t year ${ }^{-1}$ produced in the whole scattered bare areas and $42 \mathrm{t} \mathrm{year}^{-1}$ in the two landslide scars).

As illustrated before, from field evidence this amount of sediment produced is not expected to reach the basin outlet because of the lack of significant sediment transfer.

On the other hand, the analysis of the main hydrological and sediment transport events, produced during the study period (LLORENS, 1991), indicates that the pattern of solids export is clearly dominated by dissolved solids transport (TDS), that is 4 times greater than suspended solids transport (TSS) and about 100 times greater than bedload (fig. 11). This represents a total annual exportation of solids of about $3 \mathrm{tn}$ year' (being $2.6 \mathrm{tn}$ year the contribution of dissolved solids). 


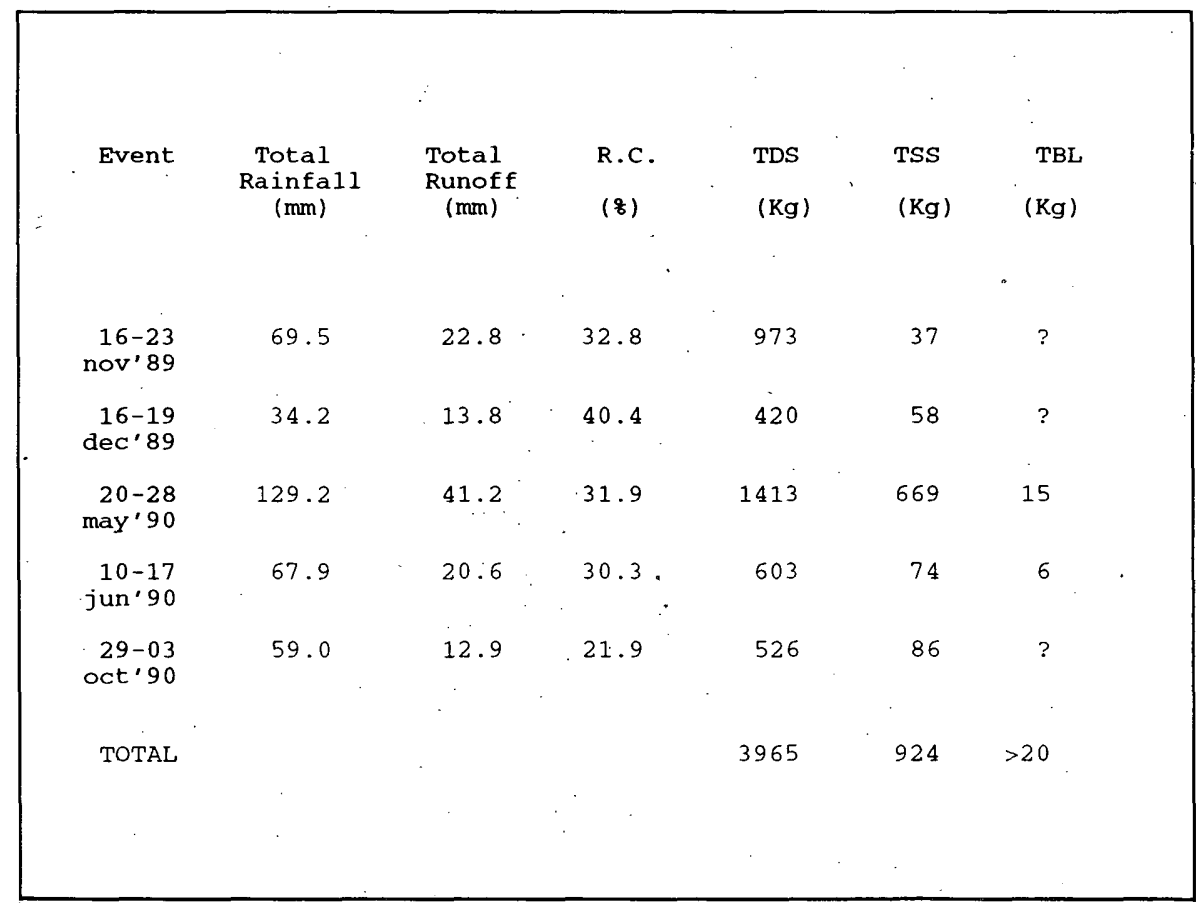

Figure 11: Main hydrological and sediment transport events of the studied period (left subbasin). (Principales eventos hidrológicos y de transporte de sedimentos del periodo de estudio (subcuenca izquierda.)

An explicit representation of the sediment budget for the studied subbasin is presented in figure 12. As commented before, this figure clearly illustrates that sediment coming from grassed terraced area is irrelevant, in contrast with the important eroșion rates in bare areas and also the marked sediment conveyance discontinuities.

Although the sub-basin sediment yield is more representative of forested stable areas than of those affected by human activities and prone to badland development, the sediment volume eroded and conveyed in the sub-basin is significant and manifests that in the present-day conditions the basin is far from equilibrium.

\section{3. hydro-morphology:}

Using the G.I.S., the superposition of the Topographical Index map with the digitized saturated areas map has given some interesting results:

40 


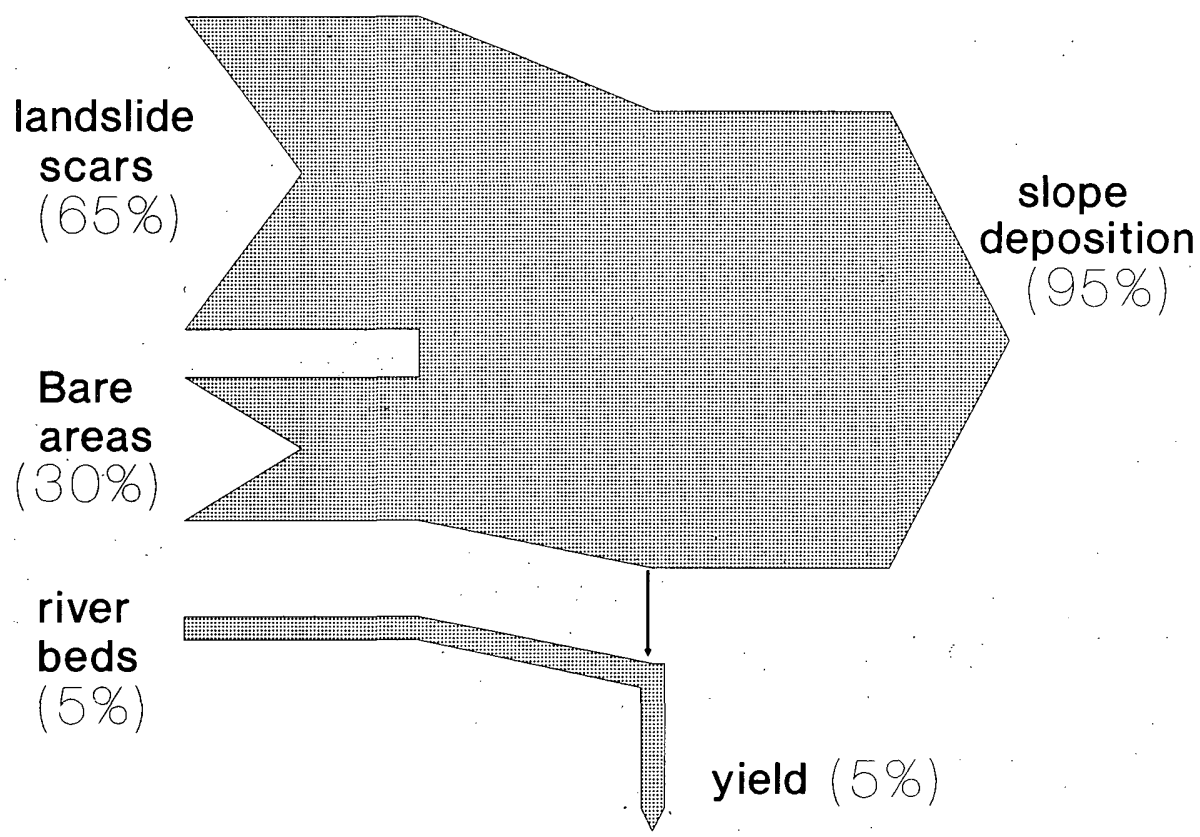

\section{Sediment sources}

\section{Sediment sinks}

Figure 12: Short-term sediment budget of the Cal Parisa left sub-basin. (Balance de sedimentos a corto plazo de la subcuenca izquierda de Cal Parisa.)

It appears that in the basin the Topographical Index of these frequently saturated areas ranges from 5.4 to 13.9 with a maximal frequency for a value of 6.7 .

The distribution of the saturated areas in terms of the Topographical Index is not a normal one, but shows a marked bimodal nature which is even more clear if we divide each relative frequency by the frequency of its corresponding Topographical Index value in the basin, as is illustrated by the test of the probabilistic plot (fig. 13).

Then, if we distinguish the two types of saturated areas (natural or anthropic) defined on the map, we observe (figs. 13 and 14) that each of the two peaks of the bimodal distribution is formed by the nearly normal distribution of one type of saturated areas.

The first peak is formed by anthropic saturated areas having a relatively low Topographical Index, about 7, while the second one is made by the natural saturated areas characterized by a Topographical Index of about 10.

On the basis of this bimodal distribution we can judge that the construction of terraces has promoted a reorganisation of the distribution of the saturated 
PIRINEOS . 139

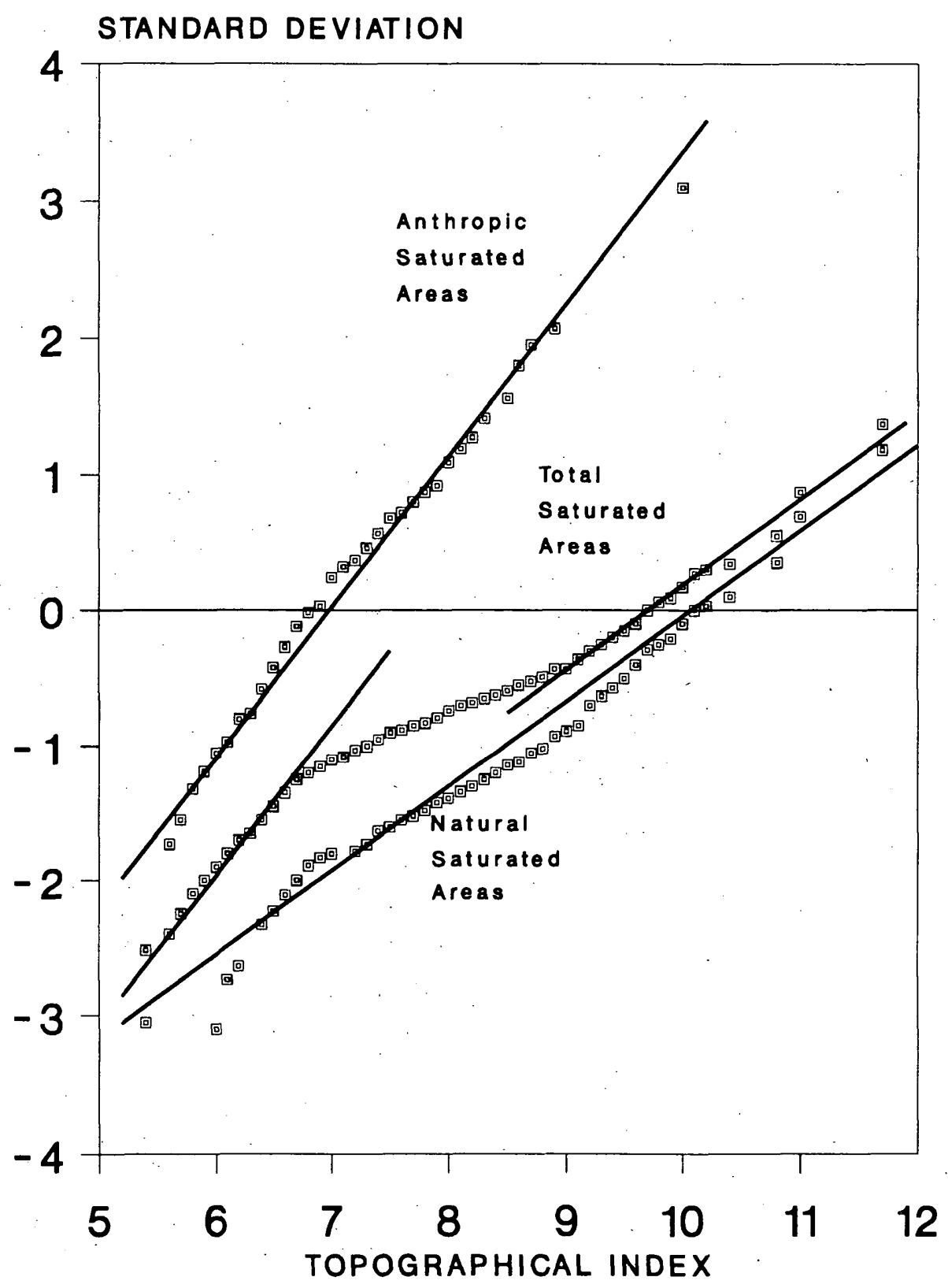

Figure 13: Probabilistic plot test for the weighted frequency distribution of classified saturated areas. (Representación probabilistica de la distribución de la frecuencia ponderada de las áreas saturadas diferenciadas.)

42 


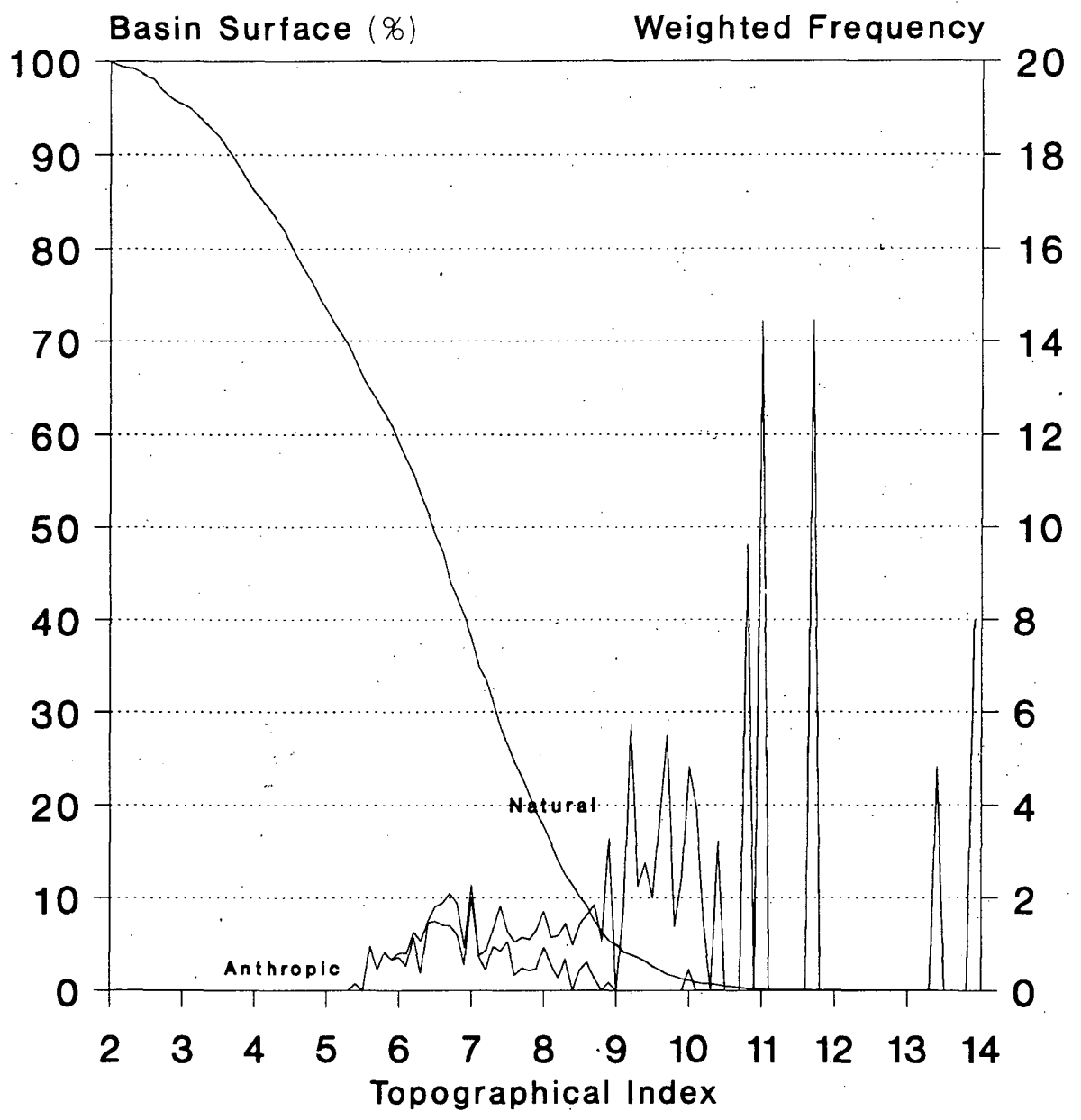

Figure 14: Topographical Index and weighted frequency distributions of the classified saturated areas. (Distribución del Indice Topográfico y de las frecuencias ponderadas de las áreas saturadas diferenciadas.)

areas, shifting it from a natural one, mainly controlled by the original topography, to a more anthropic one which shows the role of the new terraced topography and its associated artificial drainage net.

Continuing with the use of the G.I.S., it is possible to determine some characteristics of the saturated areas, and to bring out differences between the natural and the anthropic ones.

The overlap of the saturated areas map with the maps of altitude and gradient, shows that anthropic saturated areas are generally found in more 
extreme topographic conditions (at a higher altitude and on steeper hillslopes) than the natural ones that occupy more moderate situations.

The explanation for this is obviously the need, in order to cultivate these extreme topographic conditions, to build terraces higher on the hillslope. The subsurface water circulation is then changed, promoting the apparition of phreatic water and consequently modifying the spatial distribution of the saturated areas along the hillslope.

Finally the G.I.S. allowed us, by comparing the bare areas map with the saturated areas map, to estimate the role of saturated areas and drainage ditches in the development of local erosion processes.

Most saturated areas are located in the inner part of terraces where soils, when they exist, are very thin, thus promoting the outcrop of the clayey bedrock, characterized by a weak structural stability. Therefore any water concentration is able to develop some erosion processes in such areas where bedrock is not protected by soils.

This sensitivity to erosion even increases when the saturated area is connected to a drainage ditch, irrespective of the lack of a good sediment transfer because of the irregularities of the net.

Due to land abandonment and to the absence of maintenance, most of drainage ditches nowadays act in an anarchic way, promoting the apparition of non controlled concentrated runoff. This concentrated runoff is therefore the origin of future serious erosion processes, as it tries to find a way imposed by the original topography of the basin through its present terraced topography.

In the Cal Parisa basin more than $17 \%$ of the total bare area is directly located in a saturated area or on an elementary drainage axe. Among this $17 \%$, only one third concerns natural saturated areas or natural drainage axes, stressing the importance of the anthropic drainage system in the apparition of erosion processes.

\section{Discussion and conclusions}

The above observations suggest that modifications produced by terracing enhance a quick response of the basin because of the outcrop of phreatic waters on the inner part of the terraces, and the conveyance of runoff by the net of ditches. On the other hand, however, water retention may have been increased by terracing because of the formation of deeper soils with a more open structure. More research is needed to describe the stockage and movement of the water within the terraces and to understand the behaviour of saturated areas throughout the year and during rainfall events.

Sediment yield from this basin is very low, showing that terracing is an efficient land conservation system, with low sediment yield and able to buffer sediment transport coming from small but very active areas. The artificial drainage net is perceived as the critical subsystem, suffering the higher hydrological and geomorphical work, to the point that it could produce 
gullies which counterbalance the efficiency of the terrace system (see an example in GaLLART, 1991).

Nevertheless, the present-day hydrological and geomorphical behaviour of this basin is only a point within a transition between an older behaviour strongly influenced by the human activity, and a forthcoming behaviour after some new equilibrium with natural conditions will be reached.

The period of the first few years after abandonment, which has been here studied, is probably indeed the most stable, because of the growth of permanent vegetation (dense pastures, bushes and pine trees) on the formerly cultivated fields, with the permanence and activity of the old land conservation structures. The lack of maintenance of terraces and ditches can lead first to an increase of the general phreatic level (higher risk of mass movements) and afterwards to a rearrangement of the drainage net (risk of gulling).

As well as the problems of land conservation and geomorphic hazards, it can be presumed that spontaneous substitution of fields and pastures by a dense forest cover will reduce runoff contribution from these areas because of a significant increase of interception losses (see CALDER, 1991).

\section{Acknowledgements}

This research work has been funded by an agreement between the CSIC and ICONA (LUCDEME research program or Fight against Desertification in the Mediterranean). Contribution from the first Author has been also through a Grant from the Departament d'Ensenyament de la Generalitat de Catalunya. Contribution from the second Author has been supported by a Grant from the ERASMUS EEC program. Funding from the CICYT through the Project NAT89-0939 also contributed to this work. We are especially indebted to Jaume Calvet and Gabriel del Barrio who helped with GIS handling. The topographical indexes have been obtained with the help of a computer program complimentarily supplied by P. Quinn, run over a DTM kindly provided by the Institut Cartogràfic de Catalunya.

\section{References}

Balasch, J.C., CAstelltort, X., LloRens, P. \& Gallart, F. (in press): Hydrological and sediment dynamics network design in a mediterranean mountainous area subject to gully erosion. I.A.H.S. Pub.

Clotet, N., GallaRt, F. \& BaLAsch, J. C. (1988): Medium-term erosion rates in a small scarcely vegetated catchment in the Pyrenees. Catena Supp. 13: 37-47.

Del BARRIO, G., VIDAL, S. \& GallaRT, F. (1990): Programas de transformación de ficheros de formato ERDAS a formato ASCII y reciprocamente. Instituto Pirenaico de Ecología.

GALLART, F. \& CLOTET, N. (1988): Some aspects of the geomorphic processes triggered by an extreme rainfall event: the November 1982 flood in the Eastern Pyrenees. Catena Supp. 13: 79-95. 
LASANTA, T. \& RUIZ-FLAÑo, P: (1990): Especialización productivay desarticulación espacial en la gestión reciente del territorio en las montañas de Europa Occidental. In: Garcia-Ruiz (Ed.): Geoecologia de las Zonas de montaña, Geoforma Ediciones, pp.267-295, Logroño.

LATRON, J. (1991): Etude des modifications de la dynamique hydromorphologique liées à la mise en terrasses et à leur abandon (Bassin de Cal Parisa, Pyrénées Catalanes). Memoire D.E.U.S. Environment, Université Louis Pasteur, Strasbourg: 67 p.

LloRENS, P. (1991): Resposta hidrológica i dinàmica de sediments en una petita conca pertorbada de muntanya mediterránia. Ph. D. Thesis, Univ. of Barcelona, 277 p., Barcelona.

LLORENS, P. \& GALLART, F. (1991): Short-term sediment budget for a small drainage basin in a mountainous abandoned farming area. I.A.H.S. Pub. 203: 63-71.

LLORENS, P. \& GALLART, F. (1992): Small basin response in a mediterranean mountainous abandoned farming area. Catena 19

MARTIN-VIDE, X., LLASAT, C. \& CLOTET, N. (1989): Diseño de una red pluviomètrica para el control de procesos de degradación en las vertientes. Cuenca alta del Llobregat. XI Congreso Nacional de Geografia. Madrid.

QUINN, P. F., BEVEN, K. J., MorRIS, D. G. \& MOORE, R. V. (1990): The use of digital terrain data in the modelling of the response of hillslopes and headwaters. Proc. 2nd British Hydrol. Soc. Symp. Wallingford, UK, 1.37-1.42.

SiNGH, V.P. (1988): Hydrologic systems. Vol I: Rainfall-runoff modelling. Prentice Hall, 480 p., New Jersey.

Sole, A., Josa, R., Pardini, G., Plana, F., Aringhieri, L. \& Gallart, F. (1992): How mudrock and soil physical properties influence badland formation at Vallcebre. Catena 19.

STEPHENSON, D. \& MEADOWS, M.E. (1986): Kinematic hydrology and modelling. Elsevier, 250 p., Amsterdam. 